\title{
Consistent long-term spatial gradients in replenishment for an island population of a coral reef fish
}

\author{
Scott L. Hamilton ${ }^{1, *}$, J. Wilson White ${ }^{1}$, Jennifer E. Caselle ${ }^{1}$, Stephen E. Swearer ${ }^{2}$, \\ Robert R. Warner ${ }^{1}$
} ${ }^{1}$ Marine Science Institute and Department of Ecology, Evolution and Marine Biology, University of California,
Santa Barbara, California 93106-9610, USA

${ }^{2}$ Department of Zoology, University of Melbourne, Melbourne, Victoria 3010, Australia

\begin{abstract}
The population replenishment of marine organisms is routinely characterized as highly variable and unpredictable in space and time. Using island-wide recruitment surveys of a common coral reef fish, the bluehead wrasse Thalassoma bifasciatum, in 6 summers spanning a 12 yr period (1991 to 2003), we examined whether spatial patterns of recruitment are consistent or variable through time on St. Croix, US Virgin Islands. Despite annual fluctuations in the magnitude of replenishment, recruitment intensity follows a distinct and consistent spatial gradient that differs in direction between the north (leeward) and south (windward) shores; recruitment declines from west to east on the north shore and east to west on the south shore. The rank ordering of sites on each shore was concordant when recruitment was either pooled across years (monthly variation) or pooled across months (annual variation). When the 2 highest recruitment sites on each shore were considered alone, consistent seasonal effects were also apparent, with higher recruitment from June through August on the north shore, and higher recruitment in September on the south shore. Thus, while the magnitude of recruitment is indeed variable in space and time, its qualitative pattern is predictable in this area. Results of prior investigations of larval dispersal and coastal oceanography around St. Croix shed light on the origin of the consistent recruitment patterns documented in this study. The potential for consistent spatial and temporal patterns in recruitment is an important consideration in the spatial management of marine resources.
\end{abstract}

KEY WORDS: Population replenishment - Recruitment - Spatial patterns - Thalassoma bifasciatum • St. Croix · Larval delivery $\cdot$ Dispersal $\cdot$ Self-recruitment

Resale or republication not permitted without written consent of the publisher

\section{INTRODUCTION}

In marine organisms, the pelagic larval phase is capable of relatively large-scale dispersal, which may decouple benthic adult population dynamics from local reproductive output. Local populations may be largely dependent on larval replenishment originating from sources outside that local population, though accumulating evidence suggests that dispersal may be more limited than once thought (Warner \& Cowen 2002). Nonetheless, decades of research on recruitment patterns have revealed temporally variable population replenishment for temperate fishes (Hjort 1914), marine invertebrates (Coe 1953, Gaines et al. 1985, Fisk \& Harriot 1990, Reyns \& Sponaugle 1999), and coral reef fishes (reviewed by Doherty \& Williams 1988, Doherty 1991). Consequently, the current conception of marine population dynamics stresses the highly variable and unpredictable nature of replenishment (e.g. Sale et al. 2005), in which local populations are composed of cohorts originating from intermittent recruitment events mediated by unpredictable survival and dispersal in the pelagic phase (Victor 1983, Doherty \& Fowler 1994). Variable levels of recruitment 
may dramatically influence local population density, demographic rates, and community structure (Doherty \& Fowler 1994, Caley et al. 1996, Doherty 2002).

Temporal variation in the intensity of replenishment is commonly reported for coral reef fishes and is attributed to processes such as seasonal patterns of reproduction (Hunt von Herbing \& Hunte 1991), lunar cyclic production and lunar settlement cues (Robertson 1992, Sponaugle \& Cowen 1997), and physical forcing on larval transport (Milicich 1994, Dixon et al. 1999, Robertson et al. 1999, Wilson \& Meekan 2002). Inter-annual fluctuations in the magnitude of replenishment are characteristic of most reef fish (reviewed by Doherty \& Williams 1988, Doherty 1991) and may vary by several orders of magnitude in extreme cases (Robertson 1988, Stimpson 2005). Year-to-year variation in recruitment intensity may be determined by variable levels of production or stochasticity in the pelagic environment, although it is often difficult to directly assess these mechanisms. In any case, few studies document long-term patterns, be they variable or coherent. For coral reef fish, few data sets span 10 or more years (but see Doherty \& Fowler 1994, Robertson et al. 1999, Booth et al. 2000) and most studies have focused on recruitment to the relatively small spatial scales of patch reefs or lagoons.

It is still an open question whether spatial recruitment variability mirrors temporal variability, and the answer will depend on the scale of the observation. On large spatial scales (up to 1000s of $\mathrm{km}$ ) marine populations are likely to be ecologically closed, and recruitment patterns often differ consistently among regions (Doherty 1987, Fowler et al. 1992). At these scales, variability in recruitment can be principally attributed to variation in production and larval survivorship due to large-scale differences in environmental conditions. At the other extreme, small-scale $(<1 \mathrm{~km})$ studies of spatial variation in recruitment, especially those on patch reefs, emphasize extreme fluctuations in the patterns of replenishment (Williams \& Sale 1981, Victor 1983, Shulman 1985). Populations at this scale are likely to be more open (that is, not affected by local production) and influenced only by variation in larval supply. Spatial variability at the smallest (patch-reef) scale will likely result from stochastic spatial mixing and larval settlement preferences. However, on intermediate spatial scales (i.e. mesoscale, 10 to $100 \mathrm{~km}$ ), marine populations may be influenced both by rates of local larval production and larval delivery to nearshore habitats (Meekan et al. 1993). At this scale, recruitment patterns often vary by species and geographic location (highly variable: Eckert 1984, Sale et al. 1984, 2005, Milicich et al. 1992, Hamer \& Jenkins 2004; spatially consistent: Caselle \& Warner 1996, Sponaugle \& Cowen 1997, Tolimieri et al. 1998, Vigliola et al. 1998). It is important to investigate the potential mechanisms generating recruitment variation (e.g. lar- val production, survivorship, and variable currents) and the mechanisms that may limit that variability (e.g. settlement preferences and consistent larval delivery). Additionally, understanding the variability or predictability of population replenishment at the mesoscale is essential because this spatial scale is most relevant to conservation and management decisions.

While the potential for spatial variability is high, in some cases oceanographic and biological factors may intersect to produce predictable, consistent patterns. Several recent studies have revealed consistent spatial patterns of coral reef fish recruitment at the mesoscale (Fowler et al. 1992, Caselle \& Warner 1996, Tolimieri et al. 1998, Booth et al. 2000); however, few have reported coherent patterns of recruitment over long temporal durations ( $>3 \mathrm{yr}$ of sampling) at this scale (e.g. Booth et al. 2000). Here we present long-term recruitment monitoring data for an island population of a coral reef fish in the Caribbean and ask whether the spatial pattern of recruitment is consistent through time. Since 1991, we have surveyed recruitment of the bluehead wrasse Thalassoma bifasciatum (Bloch), to numerous sites surrounding the island of St. Croix. Data from a 2 yr period suggested that recruitment in St. Croix was not driven by habitat availability, but followed a distinct spatial gradient, decreasing from west to east on the north shore and east to west on the south shore (Caselle \& Warner 1996).

With recruitment data collected intermittently over a 12 yr period, we describe the temporal and spatial consistency of the island-wide pattern of replenishment to St. Croix. We have also performed a detailed comparison of recruitment to 2 sites on opposite shores of St. Croix that have been the focus of intensive studies on larval dispersal and delivery patterns. We suggest that consistent physical oceanographic processes contribute to consistent patterns of larval delivery within and across years to sites on the windward and leeward shores of St. Croix.

\section{MATERIALS AND METHODS}

Study system and species. St. Croix, US Virgin Islands $\left(17.75^{\circ} \mathrm{N}, 64.75^{\circ} \mathrm{W}\right)$ is a sedimentary island in the northeast Caribbean Sea (Fig. 1). Shallow pavement reefs surround the island and a barrier reef encloses a large lagoon on the northeast shore. Extensive shallow coastal regions include a 1 to $3 \mathrm{~km}$ wide shelf along the south shore, Buck Island off the northeast shore, and Lang Bank, which extends $8 \mathrm{~km}$ eastward from St. Croix. The surface circulation in the Caribbean is predominantly westward, driven by the trade winds and thermohaline forcing (Kinder et al. 1985, Morrison \& Smith 1990). Frequent eddy formation, however, produces considerable variability in surface circulation (Kinder et al. 1985). 


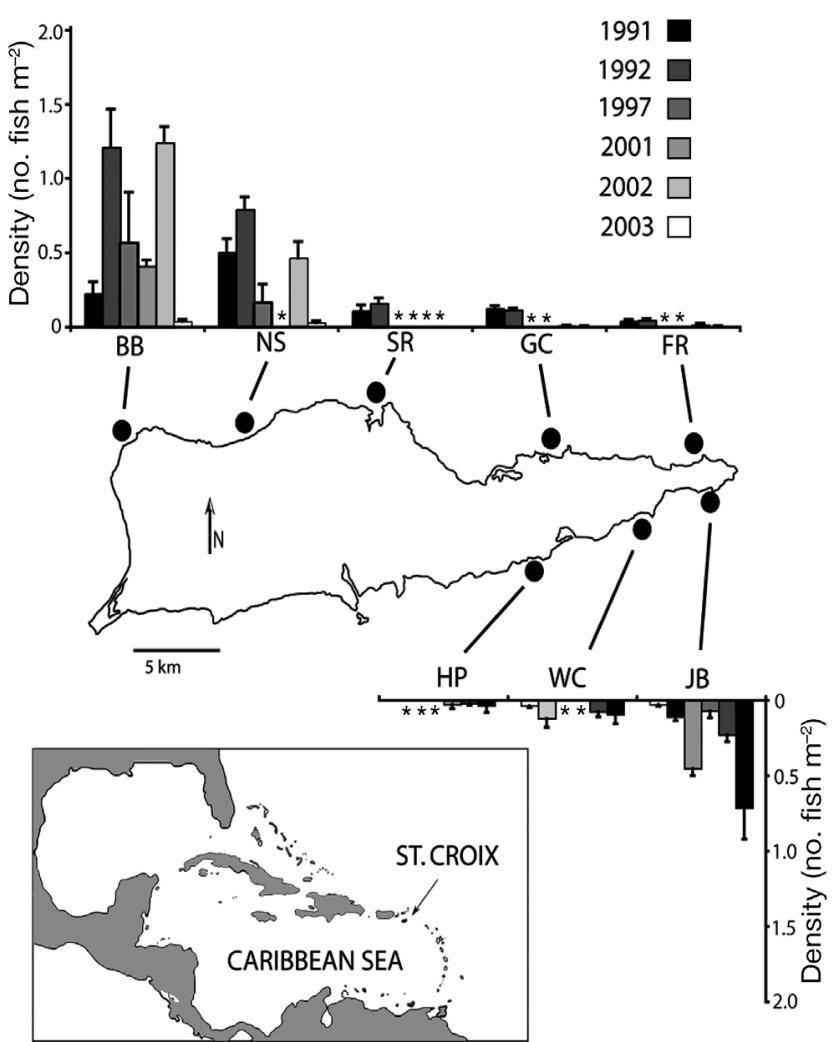

Fig. 1. Map of St. Croix showing location of study sites and mean density of Thalassoma bifasciatum recruits (no. fish $\mathrm{m}^{-2}$ ) for each year. Error bars are $\pm 1 \mathrm{SE}_{*}$ *: no data collected that year; BB: Butler Bay; NS: Northstar; SR: Salt River; GC: Green Cay; FR: Forereef; Hp: Ha'penny; WC: Wood Cottage; JB: Jacks Bay. Inset: location of St. Croix in Western Atlantic
The bluehead wrasse is a short-lived, sex-changing labrid common on shallow reefs throughout the Caribbean. It spawns daily throughout the year (Warner \& Schultz 1992); individuals settle after spending an average of 44 to $50 \mathrm{~d}$ in the plankton (Victor 1986, Caselle \& Warner 1996, Sponaugle \& Cowen 1997). At St. Croix, settlement is broadly lunar cyclic with peak intensity around the new moon (Caselle \& Warner 1996). New recruits prefer benthic, low-relief rubble or pavement habitats, though juveniles and adults (>25 mm SL) are highly mobile and shoal in the water column.

Data collection. In 1991, we established 8 sites around the island of St. Croix to survey recruitment of Thalassoma bifasciatum and other common species of reef fish. Sites were equally spaced, approximately $7 \mathrm{~km}$ from each other. All sites were located near the outer reef slope and were primarily composed of flat coral pavement with sparse patches of living and dead coral, interspersed with patches of rubble and sand. Detailed physical habitat characteristics of each site can be found in Caselle \& Warner (1996). Five sites were established on the leeward or north shore (Butler Bay, Northstar, Salt River, Green Cay, Forereef) and 3 sites were selected on the windward or south shore (Jacks Bay, Wood Cottage, Ha'penny; Fig. 1). No sites were established on the west end of the south shore due to the lack of coral habitat at shallow depths.

We censused the density of Thalassoma bifasciatum recruits at these sites during the summers of 1991, 1992, 1997, and 2001 to 2003. Census techniques varied somewhat from year to year, but the observer and technique were constant within each year (Table 1).

Table 1. Summary of sampling regimes for all years. Sampling method used each year is given with the number of transects or plots surveyed on a single date (n) and the months in which each site was surveyed (see text for details). Abbreviations: FTS: fixed transect; TS: non-fixed transect; Jn: June; Jy: July; A: August; S: September

\begin{tabular}{|c|c|c|c|c|c|c|c|c|c|}
\hline \multirow[t]{2}{*}{ Year } & \multirow{2}{*}{ Method } & \multicolumn{5}{|c|}{ - Northshore Sites - } & \multicolumn{3}{|c|}{ _ Southshore Sites } \\
\hline & & $\begin{array}{l}\text { Butler } \\
\text { Bay }\end{array}$ & $\begin{array}{l}\text { North- } \\
\text { star }\end{array}$ & $\begin{array}{c}\text { Salt } \\
\text { River }\end{array}$ & $\begin{array}{l}\text { Green } \\
\text { Cay }\end{array}$ & $\begin{array}{l}\text { Fore- } \\
\text { reef }\end{array}$ & $\begin{array}{c}\text { Jacks } \\
\text { Bay }\end{array}$ & $\begin{array}{c}\text { Wood } \\
\text { Cottage }\end{array}$ & $\begin{array}{l}\text { Ha' } \\
\text { penny }\end{array}$ \\
\hline 1991 & $\begin{array}{c}20 \mathrm{~m} \times 2 \mathrm{~m} \\
\text { FTS }(\mathrm{n}=5-6)\end{array}$ & Jy, A, S & $\mathrm{Jy}, \mathrm{A}, \mathrm{S}$ & Jy, A, S & $\mathrm{Jn}, \mathrm{Jy}, \mathrm{A}, \mathrm{S}$ & $\mathrm{Jn}, \mathrm{Jy}, \mathrm{A}, \mathrm{S}$ & Jy, A & Jy & Jy \\
\hline 1992 & $\begin{array}{c}20 \mathrm{~m} \times 2 \mathrm{~m} \\
\text { FTS }(\mathrm{n}=5-6)\end{array}$ & $\mathrm{Jn}, \mathrm{Jy}, \mathrm{A}, \mathrm{S}$ & $\mathrm{Jn}, \mathrm{Jy}, \mathrm{A}, \mathrm{S}$ & $\mathrm{Jn}, \mathrm{Jy}, \mathrm{A}, \mathrm{S}$ & $\mathrm{Jn}, \mathrm{Jy}, \mathrm{A}, \mathrm{S}$ & $\mathrm{Jn}, \mathrm{Jy}, \mathrm{A}, \mathrm{S}$ & $\mathrm{Jn}, \mathrm{A}, \mathrm{S}$ & $\mathrm{A}, \mathrm{S}$ & $\mathrm{A}, \mathrm{S}$ \\
\hline 1997 & $\begin{array}{c}6.25 \mathrm{~m}^{2} \text { plot } \\
(\mathrm{n}=7-8)\end{array}$ & Jy, A & Jy, A & & & & Jn, Jy, A & & Ju, Jy, A \\
\hline 2001 & $\begin{array}{c}20 \mathrm{~m} \times 2 \mathrm{~m} \\
\mathrm{TS}(\mathrm{n}=4)\end{array}$ & $\mathrm{Jn}, \mathrm{Jy}, \mathrm{A}$ & & & & & $\mathrm{Jn}, \mathrm{Jy}, \mathrm{A}$ & & \\
\hline 2002 & $\begin{array}{l}25 \mathrm{~m} \times 2 \mathrm{~m} \\
\operatorname{FTS}(\mathrm{n}=4)\end{array}$ & Jy, A & Jy, A & & Jy, A & Jy, A & Jy, A & Jy, A & \\
\hline 2003 & $\begin{array}{l}25 \mathrm{~m} \times 2 \mathrm{~m} \\
\text { FTS }(\mathrm{n}=4)\end{array}$ & Jy, A, S & Jy, A, S & & Jy, A, S & Jy, A, S & Jy, A, S & $\mathrm{Jy}, \mathrm{A}, \mathrm{S}$ & \\
\hline
\end{tabular}


In 1991, either 5 or 6 fixed linear transects $(20 \mathrm{~m} \times 2 \mathrm{~m})$ were established at each site in an area encompassing $\sim 500 \mathrm{~m}^{2}$ of habitat. Transects were placed haphazardly within each site, roughly $25 \mathrm{~m}$ apart in similar habitat at a depth of 3 to $5 \mathrm{~m}$. During the 1991 and 1992 recruitment seasons, recruit density on these transects was surveyed each month by 2 observers at each site. Censuses for a given month were completed at all sites in a $5 \mathrm{~d}$ period commencing 10 to $14 \mathrm{~d}$ following the new moon. In 2001, recruitment of $T$. bifasciatum was monitored at only 2 of the sites (Butler Bay and Jacks Bay). Four random transects $(20 \mathrm{~m} \times 2 \mathrm{~m})$ were haphazardly surveyed at each site throughout the month. In 2002 and 2003, we surveyed recruitment at 6 of the original sites (Salt River on the north shore and Ha'penny on the south shore were excluded). Four fixed transects $(25 \mathrm{~m} \times 2 \mathrm{~m})$ were haphazardly established in similar locations as those during the original 1991 and 1992 surveys, and censused by a single observer each month. Censuses for a given month were completed at all sites between 10 and $21 \mathrm{~d}$ following the new moon. In all 5 years, new recruits (i.e. fish which had settled in the month since the previous census) were distinguished from older fish based on their size, behavior, and location (see 'Methods' in Caselle \& Warner 1996).

Survey methods differed in 1997, when Thalassoma bifasciatum recruitment was monitored at 2 of the sites along the north shore (Butler Bay, Northstar) and 2 of the sites along the south shore (Jacks Bay, Ha'penny) as part of a study examining patterns of larval dispersal around St. Croix (Swearer 2001). Eight permanent quadrats $(2.5 \mathrm{~m} \times 2.5 \mathrm{~m})$ were established in habitats similar to those surveyed in the other years. Four quadrats were placed in the sand/coral rubble interface near the margins of reefs and 4 quadrats were situated on reefs (primarily coral pavement with isolated live coral colonies). At each site, 2 observers monitored quadrats on a weekly basis. All quadrats were surveyed over a $2 \mathrm{~d}$ period to minimize any bias due to the effects of post-settlement mortality. All fish were removed from the quadrats at the end of each census so the next week's recruits could be easily identified.

Data organization and analysis. Thalassoma bifasciatum tends to recruit in monthly pulses, generally lasting $14 \mathrm{~d}$ and centered on the new moon each month. To ensure consistency across months and years, we limited our analysis to surveys conducted between 10 and $21 \mathrm{~d}$ after the new moon, the period just after the pulse had ceased. While T. bifasciatum recruits year-round, peak recruitment occurs during the summer months (Hunt von Herbing \& Hunte 1991, Caselle \& Warner 1996, Robertson et al. 1999), so we restricted our analyses to between June and September.
To reexamine Caselle \& Warner's (1996) finding that the north and south shores of the island exhibit distinct, temporally consistent recruitment gradients, we analyzed the spatial and temporal pattern of recruit abundance separately for the 2 shores. Interannual differences in sampling techniques and observers precluded a direct comparison of recruit densities across years. To correct this potential source of bias, we standardized all data within each year as:

$$
\hat{r}_{x m y}=\frac{r_{x m y}}{\bar{r}_{. . y}}
$$

where $\hat{r}_{x m y}$ is the standardized recruitment to site $x$ in month $m$ and year $y_{i} r_{x m y}$ is the mean recruitment across all transects to site $x$ in month $m$ and year $y$; and $\bar{r}_{. . y}$ is the mean recruitment across all sites and months in year $y$. The variance of $\hat{r}_{x m y}$ is simply the variance of $r_{x m y}$ divided by the same normalizing constant, $\bar{r}_{\text {..y }}$. After transformation, the mean recruitment across all sites in any year is unity; recruitment at any one site in a particular month is measured as the proportional deviation from this mean. This transformation allows us to isolate spatial and seasonal patterns despite annual differences in either methodology or actual recruit density. Because we separated our analysis by shore, the standardization used the mean annual recruitment to all sites on the relevant shore only.

We were unable to find a transformation that eliminated the extreme heteroscedasticity among sites in our dataset, so we used the nonparametric Kendall's coefficient of concordance (Sokal \& Rohlf 1995) to test for consistent spatial and temporal recruitment patterns. We examined the similarity in the rank standardized recruitment among sites for each month averaged over all years (monthly variation) and for each year averaged over all months (annual variation). We calculated the mean standardized recruitment for a given site in a particular month or year by taking the mean of standardized recruitment values for each sampling date $\left(\hat{r}_{x m_{Y}}\right)$ weighted by their variances, as suggested by Gurevitch \& Hedges (2001). This conservative method for calculating means gives more weight to sampling dates with lower variance and prevents an unusually high census value on a single transect from exerting undue influence on the overall mean. Data from 2001 were not used in these analyses, because they consist of only one site from each shore. We were unable to test for annual variation on the south shore due to inconsistent sampling of the Wood Cottage and Ha'penny sites. Salt River was excluded from the annual trend analysis on the north shore because it was only sampled in 3 of the years.

Past data suggested that Butler Bay and Jacks Bay experienced the highest recruitment on the north and south shores, respectively, and they were the most 
thoroughly sampled sites through time in our dataset. The Thalassoma bifasciatum populations at these sites have also been the focus of otolith chemistry analysis of larval dispersal patterns (Swearer et al. 1999). As such, we selected these sites as examples of general shore-wide trends and compared the spatial and temporal pattern of recruit densities between the 2 sites using a 2-factor ANOVA with site and month (pooled across all 6 yr) as main effects and a site by month interaction. By log-transforming the raw data prior to standardizing them, using the formula in Eq. (1) (with the mean annual log-transformed recruitment to Butler Bay and Jacks Bay in the denominator), we met the parametric assumptions of normality and homoscedasticity. Because our sampling design was not fully balanced (Table 1) and samples sizes were unequal across treatments, we performed the ANOVA using the unweighted means method (Winer et al. 1991).

\section{RESULTS}

\section{Shore-wide comparisons}

Across all years of the study, Thalassoma bifasciatum recruitment followed consistent but opposing spatial patterns on the north and south shores of St. Croix. On the north (leeward) shore, recruitment was consistently highest at the western sites (Butler Bay and Northstar) and declined towards the east; on the south (windward) shore, recruitment was always highest at Jacks Bay, the easternmost site, and declined towards the west (Fig. 1).

On the north shore, recruitment declined from west to east throughout the summer (Fig. 2A). The rank order of sites with respect to recruit density followed the west-east trend and was concordant across all 4 mo (Butler Bay > Northstar > Salt River > Green Cay > Forereef; Kendall's coefficient of concordance: $W=$ 0.89, $\mathrm{p}=0.007$ ) and across all years (Butler Bay $>$ Northstar > Green Cay > Forereef; Kendall's coefficient of concordance: $W=0.83, \mathrm{p}=0.019$ ).

Along the south shore, recruitment declined westward from Jacks Bay in all months (Fig. 2B). The rank order of sites with respect to recruit density always followed the east-west trend (Jacks Bay > Wood Cottage $>$ Ha'penny; Kendall's coefficient of concordance: $W=$ $1, \mathrm{p}=0.050)$.

\section{Butler Bay-Jacks Bay comparison}

During June, July, and August, recruitment was always higher at Butler Bay than Jacks Bay, and recruitment increased through the summer at Butler

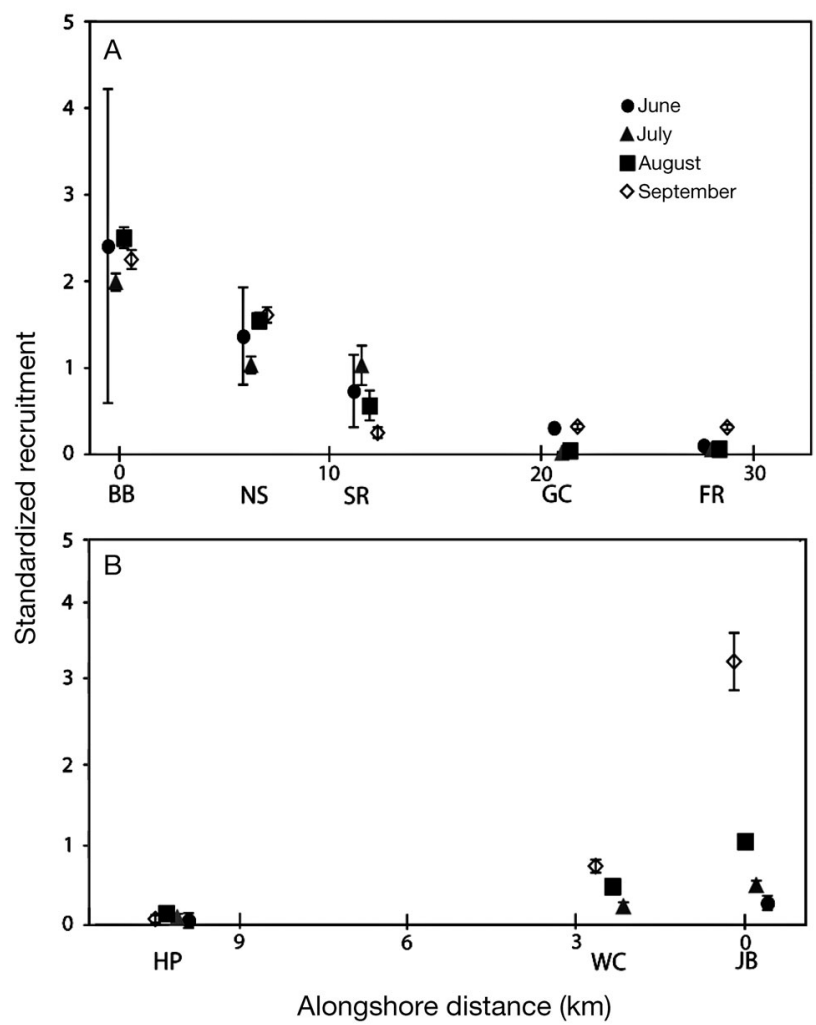

Fig. 2. Thalassoma bifasciatum. Mean standardized recruitment (dimensionless) of $T$. bifasciatum in each month along the (A) north shore and (B) south shore of St. Croix. The $x$-axis is alongshore distance $(\mathrm{km})$ from the westernmost site, Butler Bay (A), or the easternmost site, Jacks Bay (B). Note difference in scale of the $x$-axes. Error bars are $\pm 1 \mathrm{SE}$; some error bars are obscured by data marker. Site abbreviations as in

Fig. 1. Data markers are horizontally offset for clarity

Bay (Fig. 3). However, in September recruitment decreased to June levels at Butler Bay but increased dramatically at Jacks Bay, a significant reversal of the general monthly trend between the 2 sites (month $\times$ site effect in ANOVA; Table 2, Fig. 3).

\section{DISCUSSION}

Although the current paradigm regarding recruitment in marine systems emphasizes the highly variable and unpredictable nature of population replenishment across space and through time (e.g. Sale et al. 2005), we have described a consistent spatial pattern of recruitment for Thalassoma bifasciatum that has remained stable over a 12 yr period. Recruitment intensity was highly variable in space and differed by more than an order of magnitude among sites on St. Croix, yet the pattern was surprisingly predictable. Consistent recruitment gradients exist on both the north (leeward) and south (windward) shores of the island, and 


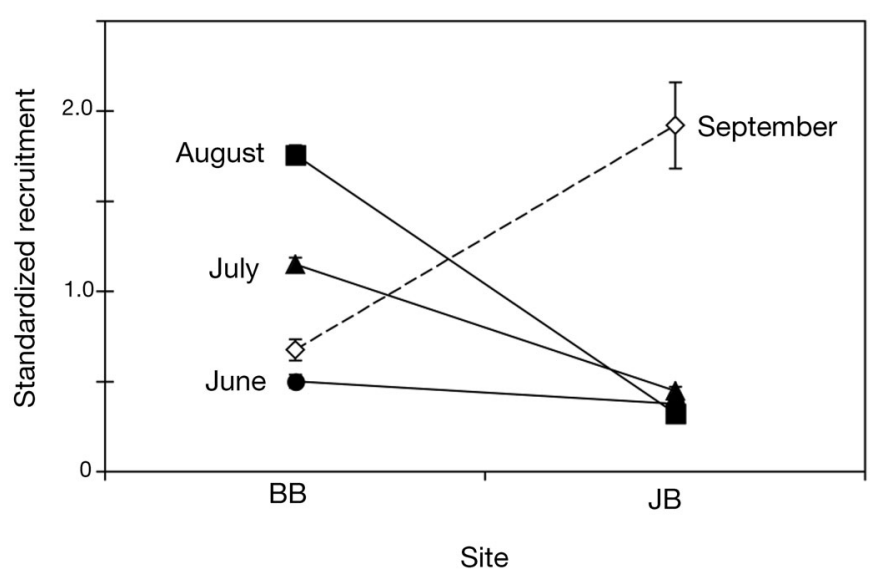

Fig. 3. Thalassoma bifasciatum. Mean standardized recruitment (dimensionless) of $T$. bifasciatum in each month at Butler Bay (BB) and Jacks Bay (JB). Error bars are $\pm 1 \mathrm{SE}$; some error bars are obscured by data marker. Log-transformed data were used in ANOVA (see text); these data are untransformed

strikingly, the patterns are shore-specific and opposite in direction. On the north shore, the intensity of recruitment peaks on the western end of the island (Butler Bay) and declines sharply towards the east. In contrast, recruitment to the south shore peaks at the eastern end of the island (Jacks Bay) and decreases towards the west. The rankings of sites in terms of standardized recruitment intensity were concordant on each shore when the data were pooled across years (monthly variation) or pooled across months (annual variation). The temporal pattern of recruitment was also consistent within years at our 2 focal sites: the intensity of recruitment increased at Butler Bay throughout the summer and declined in September, while population replenishment tended to be low at Jacks Bay throughout the summer with a large pulse of recruitment arriving in September of each year.

Other research on St. Croix supports the pattern of a distinct spatial gradient in recruitment of fish and other marine organisms along the north shore. Danilowicz et al. (2001) report the existence of a similar recruitment

Table 2. Thalassoma bifasciatum. Summary of analysis of variance (unweighted means method) on standardized logtransformed recruitment of T. bifasciatum at Butler Bay and Jacks Bay. Recruitment is standardized by year within those 2 sites only. ${ }^{*} \mathrm{p} \leq 0.05,{ }^{* *} \mathrm{p} \leq 0.0001$

\begin{tabular}{|lrrc|}
\hline Source & df & MS & \multicolumn{1}{c|}{$F$} \\
\hline Lunar month & 3 & 2.33 & $4.97^{*}$ \\
Site & 1 & 0.23 & 0.48 \\
Month $\times$ Site & 3 & 33.04 & $70.44^{* *}$ \\
Error & 46 & 0.47 & \\
\hline
\end{tabular}

gradient on a small $(7 \mathrm{~km})$ portion on the north shore for Thalassoma bifasciatum during 1996 (a year from which we lack data). Intermittent surveys of $T$. bifasciatum in 1990 and 1993, which are not included in our analysis, also follow the island-wide pattern of recruitment reported here (J. E. Caselle unpubl. data). Furthermore, Miller et al. (2003) describe a gradient in abundance of recently recruited urchins, Diadema antillarum, that decreases from west to east along the north shore from Green Cay to Tague Bay (Forereef).

\section{Mechanisms contributing to consistent recruitment on St. Croix}

Spatial patterns of recruitment intensity may be explained by differences among locations in postsettlement mortality, habitat selection, or larval delivery. We will consider these hypotheses in turn. Caselle (1999) demonstrated that on St. Croix mortality during the first few days post-settlement is strongly densitydependent for Thalassoma bifasciatum. Since compensatory density-dependent mortality should mask large pulses of recruitment, our data may actually underestimate the magnitude of settlement events to highdensity sites. Furthermore, those sites with highest T. bifasciatum recruitment (Butler Bay and Northstar) also have elevated piscivore densities (J. W. White unpubl. data), potentially increasing per capita recruit mortality. Therefore, spatial differences in postsettlement mortality are more likely to obscure rather than generate the spatial gradients in recruitment detected in this study.

Habitat selection has been shown to influence the spatial distribution of recruitment for reef fish at small scales (Booth 1992, Tolimieri 1995) and may explain consistent recruitment patterns at small and large scales (Holbrook et al. 2000). While Thalassoma bifasciatum recruits do exhibit habitat preferences within a site, the magnitude of recruitment to sites along both shores in St. Croix does not conform to the availability of preferred habitat; often, high recruitment sites are those with the lowest percent cover of preferred juvenile habitat (Caselle \& Warner 1996). Thus both postsettlement mortality and habitat selection seem unlikely explanations for the consistent recruitment pattern we found.

Temporally predictable physical oceanographic processes in St. Croix may explain the consistent but opposing spatial gradients of population replenishment to windward and leeward shores. The major oceanographic currents in this region of the Caribbean are driven by the easterly trade winds (Kinder et al. 1985), and the south shore recruitment gradient may be explained by patch depletion or downstream filtering 
after first encounter with the island (Gaines et al. 1985, Victor 1986, Jones 1997). However, patch depletion does not explain the pattern of recruitment along the north shore, since higher recruitment sites lie downstream (i.e. to the west). Consistently high levels of recruitment to the northwest side of the island are likely a result of an area of current convergence, slow currents, and potential eddy formation that characterizes the leeward shore (Harlan et al. 2002). These features retain larvae (Boehlert et al. 1992, Swearer et al. 1999) and enhance larval reef fish abundance in nearshore waters (Cowen \& Castro 1994). Additionally, larvae may actively concentrate at particular depths and migrate vertically between stratified currents to remain nearshore (Paris \& Cowen 2004). Thus, high recruitment to the northwest shore of St. Croix may well be a result of larval accumulation in the lee of the island.

Previous research in St. Croix may explain the consistent monthly differences in recruitment to leeward and windward shores revealed by the Butler BayJacks Bay comparison. Using otolith chemistry in combination with larval growth histories, Swearer et al. (1999) suggested that recruitment of Thalassoma bifasciatum to leeward (southeastern, including Jacks Bay) and windward (northwestern, including Butler Bay) sites on St. Croix was influenced by different larval sources at different times. Individuals from June, July, and August recruitment pulses to leeward sites were often characterized by fast larval growth rates and high trace metal concentrations in their otoliths, suggesting nearshore retention. In contrast, when the intensity of recruitment increased on the windward shore during September and October, recruits to all sites tended to have slow larval growth and low trace metal concentrations in their otoliths, suggesting dispersal from upstream sources across relatively unproductive oceanic water. Harlan et al. (2002) used highfrequency radar to detect a persistent nearshore convergence region of weak currents along the leeward shore during the period of peak summer recruitment, which likely retained larvae close to shore within the wake region. Anomalous strong current reversals (eastward flow) occurred during the late summer and autumn (Harlan et al. 2002), significantly depressing reef fish recruitment at leeward sites and enhancing recruitment along the windward shore (Swearer 2001). These current reversals were associated with anticyclonic mesoscale eddy activity located south of St. Croix and resulted in the disappearance of the nearshore convergence region (Harlan et al. 2002). It is still unclear whether mesoscale eddy activity facilitates transport of fish larvae among islands or simply shifts delivery of larvae from the northwest end of St. Croix to the southeast end during large-scale current reversals.
Consistent oceanographic processes have been implicated in producing consistent spatial patterns of recruitment. Sponaugle \& Cowen (1997) reported that despite annual fluctuations in the magnitude of recruitment, consistent spatial patterns of recruitment of Thalassoma bifasciatum (and other labrids) to the leeward shore of Barbados occurred over 3 yr. Nightly tidal transport was offshore at a low recruitment site and onshore at high recruitment sites. On the southern Great Barrier Reef (GBR), Booth et al. (2000) describe persistent inter-annual spatial patterns of pomacentrid recruitment to One Tree Lagoon. One site in particular, Shark Alley, has received consistently large inputs of recruits over decadal time scales, and this was attributed to favorable oceanography and topography. In French Moorea, Schmitt \& Holbrook (2002) showed strong relationships between near-field current speed and spatial patterns of replenishment of pomacentrids to sites spaced around the island. Interestingly, each species showed a different relationship between flow and settlement intensity. Oceanographic processes may be less important than benthic processes (e.g. habitat selection) in influencing spatial patterns of replenishment of fishes that use back-reef lagoons as nursery habitats on St. Croix (Adams \& Ebersole 2004). However, these authors worked in lagoons only along the eastern end of the island, a much smaller spatial scale than the current study. From our experience, these back-reef habitats receive even lower levels of replenishment than the eastern fringing reefs we surveyed.

\section{Are patterns of recruitment consistent or variable?}

Both deterministic and stochastic processes influence levels of population replenishment. The inherent stability or variability of the recruitment pattern, however, depends on the spatial and temporal scale of the analysis. Studies on the scale of patch reefs have led researchers to conclude that recruitment is extremely variable and unpredictable. On patch reefs, Victor (1983) demonstrated extreme levels of temporal variation in settlement of Thalassoma bifasciatum in San Blas, Panama. Habitat preferences strongly influenced patterns of settlement at this scale (Victor 1986). On St. Croix, temporal variation in recruitment was large within and between years for numerous species to patch reefs within Tague Bay lagoon (Shulman 1985). Our past results also show large variation in recruitment to the fixed transects within a site in 1991 and 1992 (Caselle \& Warner 1996). In contrast to the patterns reported at small spatial scales, recruitment is often spatially consistent at regional scales. Victor (1986) found consistent spatial differences in replenishment of $T$. bifasciatum on the scale of $1000 \mathrm{~km}^{2}$ 
around Punta San Blas. At this scale, recruitment to a site was positively correlated with its proximity to the onshore current. Two multi-scale recruitment studies (Doherty 1987, Fowler et al. 1992) along the GBR suggest that the predictability of replenishment increases as the spatial scale of analysis increases from sites within a reef, to reefs within large geographical regions. In these studies, the rankings of regions in term of recruitment intensity did not change across years. However, the rankings of individual reefs within regions varied from year to year.

Patterns of recruitment on the mesoscale (10s of km) are more difficult to dichotomize as consistent or variable. Tolimieri et al. (1998) examined spatial and temporal patterns of population replenishment for 14 species at sites on 3 islands within the Virgin Islands over 2 yr. Six species (including Thalassoma bifasciatum) showed consistent spatial patterns of recruitment from year to year and the rankings of sites based on recruitment intensity did not change through time. However, the other 8 species showed significant spatial and temporal variation in their patterns of replenishment. Masterson et al. (1997) reported a large synchronous pulse of recruitment of $T$. bifasciatum to sites on 3 US Virgin Islands in 1 year, but not in 2 other years. Many researchers have reported highly variable spatial patterns of recruitment on intermediate spatial scales. For labrids (Eckert 1984) and other common fish species (Sale et al. 1984) on the southern GBR, spatial patterns of recruitment varied unpredictably among reefs and years, despite some observed consistency in the rankings of reefs across years. In a more recent study, Sale et al. (2005) measured the abundance of young-of-year (YOY) recruits of 104 species over 3 yr at 3 sites on each of 7 reefs on the southern GBR. For the 15 most common species, they detected significant interactions in YOY abundance between years and reefs or years and sites nested within reefs, indicating that recruitment is spatially and temporally variable in this system. In contrast, we have shown that at the scale of one island, in a different geographic location, spatial patterns of recruitment can be consistent through time despite visible temporal fluctuations in magnitude (see Fig. 1). The divergence of our results from those obtained from the GBR may be due to differences in the predictability of oceanographic regimes among study regions.

\section{Implications}

Population replenishment of Thalassoma bifasciatum on the island of St. Croix is variable in space and time. For more than a decade, however, that spatial variability has remained extremely predictable, and consistent oceanographic processes likely drive the shore-specific spatial gradient in recruitment. Island wake regions may facilitate the retention of locally produced larvae, while windward coasts may be influenced predominately by upstream production and seasonal current reversals due to mesoscale eddy activity. Consistent patterns of replenishment, like those to St. Croix, may not only allow for focused spatial management but also allow some prediction of general characteristics associated with high- or low-recruitment areas.

We urge resource managers to consider the importance of potential recruitment 'hotspots' in creating spatial management schemes (Warner et al. 2000, Caselle et al. 2003). For conservation goals, locating a high recruitment site inside a no-take zone may facilitate a rapid increase in fish abundance and biomass. In contrast, recruitment 'hotspots' could serve the goals of fisheries by enhancing catches in areas open to resource extraction. Our results stress the importance of collecting long-term data on population demographics and the insight that can be gained into the 'unpredictable' nature of population replenishment by combining traditional monitoring techniques with emerging technological advances in otolith chemistry and physical oceanography.

Acknowledgements. We thank N. Barbee, L. Bellquist, B. Ellis, A. Haupt, B. Johnston, A. Nakamura, J. Samhouri, M. Sheehy, and L. Wooninck for help in the field. Special thanks go to S. Gaines and B. Rice for assistance with statistical analyses. The manuscript was much improved by the comments of 4 anonymous reviewers. S.L.H. and J.W.W. were supported by NSF pre-doctoral fellowships. This research received financial support from NOAA-National Undersea Research Program, NSF OCE 92-01320 to R.R.W., Partnership for Interdisciplinary Studies of Coastal Ocean (PISCO), Sigma $\mathrm{Xi}$, and the Worster Foundation. This is contribution number 200 from PISCO, the Partnership for Interdisciplinary Studies of Coastal Oceans funded primarily by the Gordon and Betty Moore Foundation and David and Lucile Packard Foundation.

\section{LITERATURE CITED}

Adams AJ, Ebersole JP (2004) Processes influencing recruitment inferred from distributions of coral reef fishes. Bull Mar Sci 75:153-174

Boehlert GW, Watson W, Sun LC (1992) Horizontal and vertical distributions of larval fishes around an isolated oceanic island in the tropical pacific. Deep-Sea Res 39:439-466

Booth DJ (1992) Larval settlement patterns and preference by domino damselfish Dascyllus albisella Gill. J Exp Mar Biol Ecol 155:85-104

Booth DJ, Kingsford MJ, Doherty PJ, Beretta GA (2000) Recruitment of damselfishes in One Tree Island Lagoon: persistent interannual spatial patterns. Mar Ecol Prog Ser 20:219-230

Caley MJ, Carr MH, Hixon MA, Hughes TP, Jones GP, Menge BA (1996) Recruitment and the local dynamics of open marine populations. Annu Rev Ecol Syst 27:477-500 
Caselle JE (1999) Early post-settlement mortality in a coral reef fish and its effect on local population size. Ecol Monogr 69:177-194

Caselle JE, Warner RR (1996) Variability in recruitment of coral reef fishes: the importance of habitat at two spatial scales. Ecology 77:2488-2504

Caselle JE, Hamilton SL, Warner RR (2003) The interaction of retention, recruitment, and density-dependent mortality in the spatial placement of marine reserves. Gulf Caribb Res 14:107-117

Coe WR (1953) Resurgent populations of littoral marine invertebrates and their dependence on ocean currents and tidal currents. Ecology 34:225-229

Cowen RK, Castro LR (1994) Relation of coral reef fish larval distributions to island scale circulation around Barbados, West Indies. Bull Mar Sci 54:228-244

Danilowicz BS, Tolimieri N, Sale PF (2001) Meso-scale habitat features affect recruitment of reef fishes in St. Croix, U.S. Virgin Islands. Bull Mar Sci 69:1223-1232

Dixon PA, Milicich MJ, Sugihara G (1999) Episodic fluctuations in larval supply. Science 238:1528-1530

Doherty PJ (1987) The replenishment of populations of coral reef fishes, recruitment surveys, and the problems of variability manifest on multiple scales. Bull Mar Sci 41: 411-422

Doherty PJ (1991) Spatial and temporal patterns in recruitment. In: Sale PF (ed) The ecology of fishes on coral reefs. Academic Press, London, p 261-293

Doherty PJ (2002) Variable replenishment and the dynamics of reef fish populations. In: Sale PF (ed) Coral reef fishes: dynamics and diversity in a complex ecosystem. Academic Press, London, p 327-355

Doherty PJ, Fowler AJ (1994) An empirical test of recruitment limitation in a coral reef fish. Science 263:935-939

Doherty PJ, Williams DMcB (1988) The replenishment of coral reef fish populations. Oceanogr Mar Biol 26:487-551

Eckert GJ (1984) Annual and spatial variation in recruitment of labroid fishes among seven reefs in the Capricorn/ Bunker Group, Great Barrier Reef. Mar Biol 78:123-127

Fisk DA, Harriot VJ (1990) Spatial and temporal variation in coral recruitment on the Great Barrier Reef: implications for dispersal hypotheses. Mar Biol 107:485-490

Fowler AJ, Doherty PJ, Williams DMcB (1992) Multi-scale analysis of recruitment of a coral reef fish on the Great Barrier Reef. Mar Ecol Prog Ser 82:131-141

Gaines S, Brown S, Roughgarden J (1985) Spatial variation in larval concentrations as a cause of spatial variation in settlement for the barnacle Balanus glandula. Oecologia 67: 267-272

Gurevitch J, Hedges LV (2001) Meta-analysis: combining the results of independent experiments. In: Scheiner SM, Gurevitch J (eds) Design and analysis of ecological experiments. Oxford University Press, New York, p 347-370

Hamer PA, Jenkins GP (2004) High levels of spatial and temporal recruitment variability in the temperate sparid Pagrus auratus. Mar Freshw Res 55:663-673

Harlan JA, Swearer SE, Leben RR, Fox CA (2002) Surface circulation in a Caribbean island wake. Cont Shelf Res 22: $417-434$

Hjort J (1914) Fluctuations in the great fisheries of northern Europe. Rapp P-V Reun Cons Int Explor Mer 20:1-13

Holbrook SJ, Forrester GE, Schmitt RJ (2000) Spatial patterns in abundance of a damselfish reflect availability of suitable habitat. Oecologia 122:109-120

Hunt von Herbing I, Hunte W (1991) Spawning and recruitment of the bluehead wrasse Thalassoma bifasciatum in Barbados, West Indies. Mar Ecol Prog Ser 72:49-58
Jones GP (1997) Relationship between recruitment and postrecruitment processes in lagoonal populations of two coral reef fishes. J Exp Mar Biol Ecol 213:231-246

Kinder TG, Heburn G, Green A (1985) Some aspects of the Caribbean circulation. Mar Geol 68:25-52

Masterson DF, Danilowicz BS, Sale PF (1997) Yearly and inter-island variation in the recruitment dynamics of the bluehead wrasse (Thalassoma bifasciatu, Bloch). J Exp Mar Biol Ecol 214:149-166

Meekan MG, Milicich MJ, Doherty PJ (1993) Larval production drives temporal patterns of larval supply and recruitment of a coral reef damselfish. Mar Ecol Prog Ser 93: $217-225$

Milicich MJ (1994) Dynamic coupling of reef fish replenishment and oceanographic processes. Mar Ecol Prog Ser 110:135-144

Milicich MJ, Meekan MG, Doherty PJ (1992) Larval supply: a good predictor of recruitment of three species of reef fish (Pomacentridae). Mar Ecol Prog Ser 86:153-166

Miller RJ, Adams AJ, Ogden NB, Ogden JC, Ebersole JP (2003) Diadema antillarum 17 years after mass mortality: Is recovery beginning on St. Croix? Coral Reefs 22: 181-187

Morrison JM, Smith OP (1990) Geostrophic transport variability along the Aves ridge in the eastern Caribbean Sea during 1985-1986. J Geophys Res 95:699-710

Paris CB, Cowen RK (2004) Direct evidence of a biophysical retention mechanism for coral reef fish larvae. Limnol Oceanogr 49:1964-1979

Reyns N, Sponaugle S (1999) Patterns and processes of brachyuran crab settlement to Caribbean coral reefs. Mar Ecol Prog Ser 185:155-170

Robertson DR (1988) Extreme variation in settlement of the Caribbean triggerfish Balistes vetula in Panama. Copeia 3: 699-703

Robertson DR (1992) Patterns of lunar settlement and early recruitment in Caribbean reef fishes at Panama. Mar Biol 114:527-537

Robertson DR, Swearer SE, Kaufman K, Brothers EB (1999) Settlement vs. environmental dynamics in a pelagicspawning reef fish at Caribbean Panama. Ecol Monogr 69: $195-218$

Sale PF, Doherty PJ, Eckert GJ, Douglas WA, Ferrell DJ (1984) Large scale spatial and temporal variation in recruitment to fish populations on coral reefs. Oecologia 64:191-198

Sale PF, Danilowicz BS, Doherty PJ, Williams DM (2005) The relation of microhabitat to variation in recruitment of young-of-year coral reef fishes. Bull Mar Sci 76:123-142

Schmitt RJ, Holbrook SJ (2002) Spatial variation in concurrent settlement of three damselfishes: relationships with nearfield current flow. Oecologia 131:391-401

Shulman MJ (1985) Variability in recruitment of coral reef fishes. J Exp Mar Biol Ecol 85:205-219

Sokal RR, Rohlf FJ (1995) Biometry. WH Freeman, New York

Sponaugle S, Cowen RK (1996) Nearshore patterns of coral reef fish larval supply to Barbados, West Indies. Mar Ecol Prog Ser 133:13-28

Sponaugle S, Cowen RK (1997) Early life history traits and recruitment patterns of Caribbean wrasses (Labridae). Ecol Monogr 67:177-202

Stimpson J (2005) Archipelago-wide episodic recruitment of the file fish Pervagor spilosoma in the Hawaiian Islands as revealed in long-term records. Environ Biol Fish 72: 19-31

Swearer SE (2001) Self-recruitment in coral-reef fish populations. PhD thesis, University of California, Santa Barbara 
Swearer SE, Caselle JE, Lea DW, Warner RR (1999) Larval retention and recruitment in an island population of a coral reef fish. Nature 402:799-802

Tolimieri N (1995) Effects of microhabitat characteristics on the settlement and recruitment of a coral reef fish at two spatial scales. Oecologia 102:52-63

Tolimieri N, Sale PF, Nemeth RS, Gestring KB (1998) Replenishment of populations of Caribbean reef fishes: Are spatial patterns of recruitment consistent through time? J Exp Mar Biol Ecol 230:55-71

Victor BC (1983) Recruitment dynamics of a coral reef fish. Science 219:419-420

Victor BC (1986) Larval settlement and juvenile mortality in a recruitment-limited coral reef fish population. Ecol Monogr 56:145-160

Vigliola LM, Harmelin-Vivien ML, Biagi F, Galzin R and 6 others (1998) Spatial and temporal patterns of settlement among sparid fishes of the genus Diplodus in the northwestern Mediterranean. Mar Ecol Prog Ser 168:45-56

Editorial responsibility: Charles Birkeland (Contributing Editor), Honolulu, Hawaii, USA
Warner RR, Cowen RK (2002) Local retention of production in marine populations: evidence, mechanisms, and consequences. Bull Mar Sci 70:245-249

Warner RR, Schultz ET (1992) Sexual selection and male characteristics in the bluehead wrasse, Thalassoma bifasciatum: mating site acquisition, mating site defense, and female choice. Evolution 46:1421-1442

Warner RR, Swearer SE, Caselle JE (2000) Larval accumulation and retentions: implications for the design of marine reserves and essential fish habitat. Bull Mar Sci 66:821-830

Williams DMcB, Sale PF (1981) Spatial and temporal patterns of recruitment of juvenile coral reef fishes to coral habitats within 'One Tree Lagoon', Great Barrier Reef. Mar Biol 65: $245-253$

Wilson DT, Meekan MG (2001) Environmental influences on patterns of larval replenishment in coral reef fishes. Mar Ecol Prog Ser 222:197-208

Winer BJ, Brown DR, Michels KM (1991) Statistical principles in experimental design. McGraw-Hill, Boston, MA

Submitted: September 22, 2004; Accepted: July 18, 2005

Proofs received from author(s): November 30, 2005 